\title{
E-Learning of Foreign Languages at the University of Dubrovnik, Experiences and Attitudes of Users
}

\section{Zrinka Režić Tolj}

University of Dubrovnik, Center for languages, zrinka.rezic@unidu.hr

Lucijana Leoni

University of Dubrovnik, Center for languages, lucijana.leoni@unidu.hr

Jasenka Maslek

University of Dubrovnik, Center for languages, jasenka.maslek@unidu.hr

\begin{abstract}
At the time of computerization and digitization of modern society the use of modern technology in education is logical and natural. At the University of Dubrovnik, e-learning was implemented in 2005. Since then the number of users of the platform for e-learning is constantly increasing. The goal of the research, conducted at the beginning of 2016 at the University of Dubrovnik, using two different but similarly structured questionnaires, among teachers and their students, was to determine the degree and manner of use of Moodle platform in a hybrid language teaching (at the University of Dubrovnik), and to examine, among users of e-learning, the use of various possibilities that this system of modern way of teaching offers, as well as their attitudes on the acceptance of e-learning in foreign language teaching and learning. Research shows that the use of e-learning technology has many advantages for students but also for teachers, although it requires a lot more investment and effort from them. The attitudes on the use of modern ways of e-teaching languages are generally positive and positively affect its increasing use.
\end{abstract}

Keywords: language teaching, e-technology, e-learning, hybrid language teaching

\section{Introduction}

The city of Dubrovnik has a centenary tradition of nurturing culture, sciences and education, as a result of which the foundation of the University of Dubrovnik was a natural consequence. The University, founded in 2003, is the first Croatian university to adopt the Bologna declaration and the model of an integrated organization within it. Within its mission and goals the University of Dubrovnik adapts to changes in the scientific progress, changes in teaching methods and meets the needs of the students and expectations of its employees and the community, striving to promote the University as an institution offering global excellence in education in order to attract best possible students, national or international, promoting the international, and especially European, co-operation in higher education and science and arts. The study programs are organized in eight departments:

Economy and Business economy

Maritime department

Electrical engineering and information technology

Engineering department 
Aquaculture

Public Communications \& Mass Media

\section{Restoration and Fine Arts}

Department of humanities (still in development)

The University has the University centre for foreign languages where learning and teaching of modern languages is based on the implementation of modern technologies, including the e-learning model.

When the University of Dubrovnik was founded in 2003 there was no strategic plan in terms of the implementation of elearning technologies and tools. In 2005 the University of Dubrovnik became a member of the EU Tempus project EQIBELT (Education Quality Improvement By E-Learning Technologies). After three and a half years of continuing and hard work Tempus project EQIBELT has finished on January 31, 2009. Project had successfully fulfilled all planned goals and objectives. Universities of Dubrovnik, Rijeka and Zagreb prepared, discussed and adopted policy documents for implementation and using of e-learning. The activities that took place during the three years of the project have prompted a large number of teachers at the University of Dubrovnik to get acquainted with and introduce the e-learning models. Particularly foreign language teachers of the University centre for foreign languages have shown great interest in using elearning technologies and tools by embracing the ICT as an indispensable tool for achieving excellence in foreign language teaching. Considering its numerous advantages, let us mention only a few: flexibility (in terms of time and space) in teaching and learning; flexible approach (in terms of time and space) to actual and current multimedia and interactive teaching materials; access (offered as integral part of the teaching process) to Croatian and world repositories of teaching materials, digital libraries, archives and museums; possibility of adjustment to individual styles of learning, possibility of collaborative learning and of the development of skills for project and team work; accessibility to broader student population (students with special needs, students at distant locations, foreign students, etc).

A survey was conducted to determine students' and foreign language teachers' attitudes and satisfaction with the use of elearning language courses at the University of Dubrovnik. The aim of research was to determine the level and model of Moodle platforms in a hybrid language teaching at the University of Dubrovnik, and to ask the users of e-learning about various possibilities offered by this system of modern teaching. One of the indicators of efficacy and quality of the implementation and integration of e-learning systems in the educational system is taken to be students' satisfaction with the system and its use (Seljan, Klasnić \& Stančić, 2012).

\section{State of the art - wider context}

The experts from the Department of information and communication sciences at the Faculty of humanities and social sciences in Zagreb, who are the pioneers in the field of e-technology in classrooms with years of experience in the Croatian academic community, in 2008 helped organize the course "E-learning technologies in teaching foreign languages", which meant the beginning of creation and implementation of the first foreign language courses on-line. By 2014 e-courses of all studies at the University of Dubrovnik were posted on the e-learning platform under the name DUEL (Acronym for Dubrovnik University E-Learning). Later on the courses were relocated to the platform called "Merlin" of the University computing centre SRCE at the University of Zagreb. Both platforms use an open-source course management system (CMS) MOODLE as technical support. Due to the cost reduction for their own platform management, the University of Dubrovnik administration decided in 2014 to start using an additional e-learning host platform Merlin with an intention to completely abandon their own in future.

In the last four years for some unknown reasons the University of Dubrovnik did not take good care for the sustainability of e-learning by creating necessary preconditions through systematic planning of activities and ensuring financial resources for the application of e-learning. Teachers miss continuous support and evaluation of their work that should be implemented through provision and maintenance of the infrastructure required, and through enhancing and co-funding the development of quality e-learning teaching materials and promotion thereof. 
As a rule, at the University of Dubrovnik the mixed (blended, hybrid) form of e-learning is applied. Such approach is based on the combination of classic teaching methods and those employed in virtual learning and teaching environments. Choice of the tools and intensity of e-learning is left to the teachers. They are invited to recognize and apply the tools of e-learning which are appropriate for particular education areas, i.e. particular studies and/or courses.

In the academic year 2015/2016 the University of Dubrovnik offered the following studies:

- 13 (university) + 2 (vocational) undergraduate studies

- 12 graduate studies

- 1 postgraduate specialist study

- 8 interuniversity doctoral studies

Currently, the University of Dubrovnik has 60 foreign language courses at the DUEL platform which hosts 243 courses of all study groups, while there are 29 courses at the MERLIN host platform (it hosts 112 courses at the University of Dubrovnik). Therefore, the e-courses of foreign languages make up one fourth of the total number of e-courses at the University of Dubrovnik, regardless of the platform.

\section{Theoretical background}

E-learning is a process of education (learning and teaching process) conducted using the information and communication technology which improves the quality of the process itself and the quality of its result. Depending on the manner and intensity with which information and communication technologies (hereinafter referred to as ICT) are used, in the process of education we can distinguish several forms of e-learning: application of elementary ICT tools in otherwise classic form of teaching (face-to-face or F2F), through blended, mixed mode or hybrid teaching, i.e. a combination of classic classroom teaching methods with those using advanced ICT possibilities, and, finally, distance, fully online teaching conducted by means of ICT. To achieve successful and efficient application of e-learning, i.e. successful and efficient application of ICT, it is important to select the method and approach which correspond with the demands of a particular course and with the abilities and needs of particular teachers and students.

At the University of Dubrovnik there is a hybrid model that combines the standard teaching with the ICT tools. It turns out that this approach fully corresponds to the capabilities of teachers and students' needs while encouraging their active participation in the educational process with the permanent coordination and with improved learning outcomes. "Recent research purports to show that blended learning is more effective and students learn more and enjoy it more than on either face-to-face or online teaching alone. Blended learning combine the power and effectiveness of the classroom with the flexibility and anytime nature of e-learning and allows learning to be more tailored and more individualistic, whilst at the same time allowing greater reach and distributed delivery" (Mason \& Rennie, 2006, p. 13). Hybrid teaching enables a continuous monitoring of students' activities, their dedication, and progress. The abundance of the on-line didactic materials offers the possibility of individual work which is checked by the teacher as soon as it gets on the server. By setting a deadline for homework, a last-minute approach to work is partly avoided. The schedule determined by the curriculum (two hour lectures without exercises once a week) often leads to the last-minute approach to work. A communicational interaction is achieved in the classroom by practicing various listening strategies and a debate on a given topic. The e-course settings imply the control of receiving and reproducing the knowledge by a practical simulation in the classroom, but the main intention is to encourage the interaction at distance by wider use of the forum - conversations, discussions, and presentations. By practicing different listening strategies and a debate on a given topic this interaction is also achieved in the classroom. Occasionally, if necessary, didactic units are added to enhance or to repeat the knowledge by including useful links, glossaries, etc. Self-evaluation exercises are desirable in the class so that the teacher could evaluate them easily and get an insight into the type and level of mistakes that are immediately corrected, along with the lexis and language. This particularly refers to mistakes at the phonological level when the teacher by repetition as a linguistic modification and correction, i.e. by insisting on the correct language form, draws attention to the linguistic form (ČurkovićKalebić, 2002, p. 138). The strategy of repeating a correct language construct, especially at the grammatical level, helps 
develop communication skills and accelerates the process of becoming aware of speech structures which make the selfevaluation more successful and stimulating. In this way a combination of cognitive and meta-cognitive foreign language learning strategies leads to the evaluation of personal achievements (Božinović, 2008, p. 274).

The selection of appropriate texts helps follow the interests and orientation of students at higher learning levels, while at the same time broadening their knowledge on the civilization and culture of a particular language area. The first step in the processing of such texts is always to read the entire text and examine its context. This arises from the fact that reading does not mean translating, and that understanding of the text does not depend on the comprehension of each word. Prior knowledge has an important role in understanding the text, so the students are encouraged to go through the text by using the methods of association and generalization, while bearing in mind that the title can roughly determine the topic. The accompanying selected images taken from the internet make the topic recognizable, while the crucial help in understanding is provided by internationalisms or key words that define the main information and the content.

Among functional objectives in the e-learning, the analytical and synthetic thinking is encouraged and the exercises of analogy are favoured, while the graduality is emphasized among didactic components. Graduality is achieved by the distribution of content in larger units which help students first acquire new knowledge, i.e. the main articulation of the whole while striving to acquire new skills and habits by practicing and repeating. With the selection of an additional interesting online content (with native speakers serving as a model) such as songs, new linguistic forms are easily acquired by following these basic postulates: teaching "In the language" and not learning "about the language".

The simultaneous visualization of content enhances communication between students, commences the discussion, and thus enables new, indirect processes of adopting the content, i.e. of learning. Moreover, this hybrid learning model offers a broad range of additional activities for the students who prefer an individual approach by means of a direct on-line contact with the teacher. This provides a deeper insight into the continuity of students' activities and prevents a last-minute work. This leads to work in pairs and individual work by constantly bearing in mind the accomplishment of functional teaching goals and by using the method of analogy.

\section{Research - methods and sample}

The aim of the research entitled "E-learning of foreign languages at the University of Dubrovnik, experiences and attitudes of users" carried out by using a structured questionnaire, was to determine the level and model of Moodle platforms in a hybrid language teaching at the University of Dubrovnik, and to ask the users of e-learning about the use of various possibilities offered by this system of modern teaching. To examine these attitudes a study was conducted on the student sample $(\mathrm{N}=138)$ and on the foreign language teachers sample $(\mathrm{N}=12)$ at the University of Dubrovnik in January and February 2016. Sample description: students were from all Departments, taking languages both as compulsory or elective courses. All years of study were equally represented in the sample; teachers were foreign language teachers ( $100 \%$ female, no male teachers of foreign languages at the University of Dubrovnik), teaching languages: English, French, German, Italian and Spanish. Answers which were not relevant for the research were left out both in descriptive and tabular format.

\section{Descriptive analysis of the survey results conducted among students $(\mathrm{N}=138)$ at the University of Dubrovnik}

The research involved 138 students. The survey for students comprised the following three parts:

- the focus of the first part was on the use of e-learning (e-learning platforms, the number of active courses, frequency of use, activities), then on the students' opinion about the adequacy of its use, and whether they liked it or not

- $\quad$ the second part of the survey questioned the benefits of e-learning

- $\quad$ the third part examined its drawbacks.

The first question: "Do you use e-courses of foreign languages?" $89 \%$ of students answered yes. Out of these, $79 \%$ used only Merlin, 9\% Duel and Merlin, and the smallest number of respondents used only Duel, $4 \%$. As for the number of ecourses of foreign languages, most of them used only one course (39\%), and slightly smaller number of students (37\%) 
used two courses, partly specifying it was English, then Italian, Spanish, French, and German. Most students used these courses occasionally $(53 \%)$, then rarely $(23 \%)$, and the smallest portion of students used them constantly $(18 \%)$. When answering the question on the activities of e-learning they used, most students chose (among the offered answers) the use of lessons (28\%), then homework (27\%), and dictionary (19\%), while other activities were rarely used. When acquiring the content, homework (27\%) helped them most, along with the lessons (18\%), although these percentages should be taken with some reservation as $47 \%$ of students have not answered this question. More than half of students $(55 \%)$ said they did not use e-learning sufficiently, while $41 \%$ sufficiently used it. The vast majority of students $(80 \%)$ liked e-learning, while $15 \%$ did not prefer this way of learning. The nine mentioned benefits of e-learning were mostly perceived as such: an upto-date work $(91 \%)$, an individualized approach to learning ( $85 \%)$, availability and transparency of educational material $(92 \%)$, the benefit of on-line access to the useful online didactic and multimedia content (86\%), an interesting e-course was considered to be an advantage to a significant number of students ( $83 \%)$. The usefulness of e-courses to learn the language and to prepare exams was recognized by $88 \%$ of students. Most respondents ( $82 \%$ ) provided a positive opinion regarding the communication with teachers and the possibility to have their assignments checked. The possibility to do and deliver homework was positively assessed by $85 \%$ of respondents, but online assessments (preliminary exams, tests) were rated as negative by $42 \%$ of respondents. A constant insight of teachers into the work of students and monitoring of their progress by means of e-technology was considered a drawback by $50 \%$ of students. Only $28 \%$ of respondents thought that e-learning was demanding in terms of informatics. An insufficient number of equipped classrooms was perceived as a drawback by $45 \%$ of students. Poor organization of the teaching content was considered to be a flaw of e-learning by $29 \%$ of students. Looking for useful content was assessed as losing a lot of time by $32 \%$ of students, while $32 \%$ of students thought that unnatural communication with teachers through e-technology was a drawback. The use of e-learning in the language teaching was considered by $24 \%$ of respondents as the increase in their workload. Preparation and delivery of assignments through e-technology was considered a drawback by $39 \%$ of students, while $23 \%$ of students considered the e-assessment to be complicated, as opposed to $72 \%$ who did not consider it complicated, while $54 \%$ of students believed that this assessment was an advantage in the process of foreign language learning.

\section{Descriptive analysis of the results of a survey conducted among teachers $(N=12)$ at the Centre for Languages}

During the study entitled „E-learning (in education) of foreign languages at the University of Dubrovnik, experiences and attitudes of users" survey was sent via an e-mail to all teachers (16) of the University centre for languages containing the information about the survey and a request to respond to it, whether they are e-learning users or not. $75 \%$ of teaches from the Centre for languages participated in the research; a part of teachers $(25 \%)$ who didn't participate can be assumed not to be familiar with e-technology work and not interested in its implementation. The survey for teachers consisted of three parts:

- the first part related to the use of e-learning (platform for e-learning, the number of courses, frequency of use, activities, resources ...) and teachers' opinion on e-learning in general

- the second part of the survey questioned the benefits of e-learning according to teachers

- $\quad$ the third part was dedicated to the disadvantages of e-learning according to teachers

According to the results of analyzed questionnaires, in this academic year the e-learning in foreign language teaching is used by most of the surveyed teachers $(67 \%)$. Teachers that are not using the e-learning in the language teaching $(33 \%)$ this academic year provided the following reasons: low interest of students $(15 \%)$ and preference for standard ways of teaching languages (8\%), while none of the teachers stated as a reason an insufficient IT knowledge, or lack of courses that would train teachers for this kind of work. Almost half of teachers (42\%) are interested and would like to use e-learning in the future; although this question was addressed to the non users of e-learning $(33 \%)$ some of the users responded as well.

Regarding the platform, the following percentages were provided: teachers use mostly (only) Merlin (43\%), 36\% of teachers use both platforms (Duel and Merlin), while a small number of teachers use only Duel (14\%), mainly in the period longer than five years $(83 \%)$. According to the collected data, on the Duel platform teachers actively use the following number of courses: one course (17\%), two (8\%), six e-courses $(8 \%)$. Number of e-courses that is actively used on Merlin varies as 
well. Teachers are using mostly: one course (17\%), two courses (17\%) and six courses (17\%), while other indicated number of courses is rarely used: three courses per semester (8\%), five courses (8\%) and eight courses (8\%).

According to the answers to the question regarding the used activities, teachers listed the following: homework (27\%), vocabulary $(24 \%)$, lesson $(22 \%)$ and forum $(13 \%)$, while the use of other e-tools such as test, dialogue and wiki is insignificant. The most frequently used activities, according to most teachers are the following: tasks (22\%) and lessons $(22 \%)$, then forum (17\%) followed by dictionary (5\%). Regarding the resources in use, most teachers use files (33\%) and links (30\%), slightly fewer teachers use webpage (17\%) and significantly less use book $(7 \%)$, label $(7 \%)$ and folder $(3 \%)$. The most commonly used resource is file $(33 \%)$, followed by links $(28 \%)$. All the teachers who answered the questionnaire (92\%) like e-learning. Most teachers $(67 \%)$ do not consider e-learning demanding in technical and IT sense, and even more respondents $(92 \%)$ recognize that e-learning facilitates their job. The majority of surveyed $(92 \%)$ do not consider that students use e-learning sufficiently. There is a noticeable awareness and sincerity of the half of surveyed $(50 \%)$ regarding the insufficient use of the possibilities that e-learning offers in language teaching, although it should be noted that a large number of teachers (42\%) think that they use e-learning sufficiently. Most of the surveyed teachers $(92 \%)$ think that the use of e-learning increases the quality of work. Half of the teachers $(50 \%)$ think that there is no sufficient technical support within the institutions in designing e-courses, while $42 \%$ of respondents is satisfied with the support.

At the University of Dubrovnik $50 \%$ of teachers of foreign languages at the Centre for languages is continuously working and improving the quality of teaching by using e-learning in the hybrid teaching. Part of teachers $(25 \%)$, although familiar with the work on e-learning platforms, this academic year is not using it.

All teachers who participated in the survey $(75 \%$ of teaches from the Centre for languages) consider as advantages the following options offered through e-learning tools: the availability of e-course, individualization of learning, availability and transparency of teaching materials, links to useful online didactic and multimedia content, interesting e-course, the usefulness of e-course for language learning and exam preparation, and the possibility to monitor the work of students. Most of the teachers (92\%) considered as an advantage the possibility to represent all four language competences (reading, writing, oral language reception and production) through e-learning tools. The same percentage of teachers (92\%) perceives the possibility of e-communication with students as an advantage. Teachers are primarily polarized in relation to the development and implementation of assessment: majority (67\%) denies the advantage of e-learning, while a number of teachers (33\%) believe that the assessment via e-test is an advantage in teaching. Teachers are divided regarding the opinion on the issue and complexity of e-learning. Most teachers $(75 \%)$ determine disadvantages of a technical nature of e-learning platform. Time needed to create an e-course most teachers $(75 \%)$ consider to be a drawback. The organization of the content is not a lack for the majority of teachers $(58 \%)$, although slightly smaller number of teachers (42\%) confirms this deficiency. Time spent searching for useful online content more than half of respondents $(58 \%)$ consider as disadvantage. Most teachers (85\%) do not consider electronic communication with students unnatural. Majority of surveyed believes that students use e-courses insufficiently (92\%) and do not recognize the usefulness of e-learning (75\%). Passivity in carrying out the individual tasks represents a flaw according to most respondents $(75 \%)$, as well as the complicated implementation of assessment (83\%). The apparent discrepancy between the attitudes of students and teachers in terms of e-assessment of foreign language (language e-testing), indicate a possible mistrust of teachers for such forms of testing, while students experience e-testing as an advantage.

\section{Conclusion}

The research sought to gain an insight into the current/actual state of using e-learning models and tools in the foreign language classes and to determine the attitudes of students and their teachers about the e-learning at the University of Dubrovnik. The answers gathered through the questionnaire for students pointed to the high level of acceptance of elearning as a desirable additional learning model with much more advantages than disadvantages. The questionnaire for teachers showed similar results. It is interesting that most teachers consider e-learning a desirable teaching model with numerous benefits, regardless of the insufficient technical support from the part of their home institution. Most of the interviewed teachers want to use e-learning in future as an addition to the standard classes, even though the preparation of e-course requires a lot more effort. Research shows the use of a hybrid form of Moodle platforms in foreign language teaching at the University of Dubrovnik. Specific tools offered by this system of modern teaching, such as the possibility to 
communicate anytime and anywhere, to put the learning materials and assignments on line, are used much more than for example the tests that are rarely or never used.

So as to have the e-learning technology at the University of Dubrovnik systematically implemented, improved and preserved in foreign language classes as an integral part of the tertiary education at all levels, and in line with the needs of modern society, it is necessary to devise an e-learning strategy and for that purpose to establish an e-learning office which would continuously monitor and provide support for the e-learning implementation and strategy. E-learning office, which was envisioned by the Tempus project, was active up to the 2015 when it was shut down by the University administration, and since than its maintenance and development are left to an outside institution, i.e. to the Centre for e-learning at the University of Zagreb. Since the use of e-learning depends on the willingness of each teacher and it requires an additional engagement in classes, it would be useful to define the criteria for rewarding well made and managed e-courses. Most of the foreign language teachers and students at the University of Dubrovnik have shown through the questionnaire that they consider e-learning a benefit and added value to the standard teaching. Therefore, we believe that its application nowadays is an imperative for all of us who have the possibility to use it.

Generally E-learning could facilitate the communication between the academic community and the economy. For the city of Dubrovnik and its region are still in a traffic isolation, sustainable e-learning at the University could make possible the access to the University studies for those who have logistical problems, including the disabled students or those who are already employed. It could also help to organize modules for a life-long learning that could enable the revitalization of rural and insular localities of the region which register a demographic decrease. In some islands for example working force has to be imported in the high season in summer. So, models of e-learning could be useful in the program of tourism studies, foreign languages learning, communication studies, but also technical and maritime studies. All this would help in creating the image of the University of Dubrovnik as a modern and attractive university. Consequently the number of students would increase which would help assure the existence of the University of Dubrovnik in such a small community (fifty thousand inhabitants) trying to survive in the global "market" of knowledge that became accessible for everyone and everywhere thanks to the implementation of e-learning.

Today it is not desirable to organize classes without the use of computers. This means that the computer has largely affected the organizational teaching structure at two levels, i.e. in the teaching process and in the interaction with students. Both segments are very delicate and important for the future of education in Croatia. If the level of informatization of society is the metaphor for the advancement of society as a whole, than the level of informatization is the metaphor for the development of universities or faculties (Badurina, 2010, p. 7-8).

\section{References}

[1] Badurina, B. (2010). Model prihvaćanja novih tehnologija za učenje na daljinu na hrvatskim sveučilištima. Doktorska disertacija. Sveučilište u

[2] Božinović, N. (2008). "Razvijanje gramatičke kompetencije uz pomoć adekvatnih strategija učenja gramatike". Strani jezici 37 (3), 267-278.

[3] Čurković-Kalebić, S. (2002). "O govoru nastavnka u nastavi stranih jezika (ponavljanje pitanja i uporaba stanki)" Strani jezici 32 (3-4), 137-144.

[4] Mason, R. and Rennie, F. (2006). Elearning: the key concepts. London: Routledge.

[5] Seljan, S., Klasnić, K, \& Stančić, H. (2012). Computational language analysis. Zagreb: Zavod za informacijske studije.

[6] Zagrebu, Zagreb. Retrieved from https://bib.irb.hr/datoteka/454923.badurina_doktorat_f.pdf 


\section{Tables}

Table 1: Results of the survey for students $(\mathrm{N}=138)$

\begin{tabular}{|c|c|c|c|c|c|}
\hline No. & QUESTION & \multicolumn{2}{|l|}{ YES } & NO & $\begin{array}{l}\text { NO } \\
\text { RESPONSE }\end{array}$ \\
\hline 1. & Do you use e-courses of foreign languages? & \multicolumn{2}{|l|}{$89 \%$} & $10 \%$ & $1 \%$ \\
\hline 2. & If YES, which platform do you use? & $\begin{array}{l}\text { Duel } \\
\text { Merlin } \\
\text { Duel \& Merlin }\end{array}$ & $\begin{array}{l}4 \% \\
79 \% \\
9 \% \\
\end{array}$ & $0 \%$ & $8 \%$ \\
\hline 3. & How many e-courses do you use? & $\begin{array}{l}1 \text { course } \\
2 \text { courses } \\
3 \text { courses } \\
\text { other responses }\end{array}$ & $\begin{array}{l}39 \% \\
37 \% \\
3 \% \\
3 \% \\
\end{array}$ & $0 \%$ & $22 \%$ \\
\hline 4. & How often do you use e-courses? & $\begin{array}{l}\text { occasionally } \\
\text { rarely } \\
\text { always }\end{array}$ & $\begin{array}{l}53 \% \\
23 \% \\
18 \% \\
\end{array}$ & $0 \%$ & $6 \%$ \\
\hline 5. & Which e-learning activities do you use? & $\begin{array}{l}\text { lesson } \\
\text { assignment } \\
\text { dictionary } \\
\text { test } \\
\text { wiki } \\
\text { dialogue } \\
\text { forum } \\
\text { other responses }\end{array}$ & \begin{tabular}{l|}
$28 \%$ \\
$27 \%$ \\
$19 \%$ \\
$11 \%$ \\
$5 \%$ \\
$3 \%$ \\
$2 \%$ \\
$1 \%$ \\
\end{tabular} & $0 \%$ & $4 \%$ \\
\hline 6. & Which activities you use most? & $\begin{array}{l}\text { assignments } \\
\text { lessons } \\
\text { dictionary } \\
\text { wiki } \\
\text { test } \\
\text { other responses }\end{array}$ & \begin{tabular}{l|}
$21 \%$ \\
$18 \%$ \\
$5 \%$ \\
$3 \%$ \\
$2 \%$ \\
$4 \%$ \\
\end{tabular} & $0 \%$ & $47 \%$ \\
\hline 7. & Do you sufficiently use e-learning possibilities? & & $41 \%$ & $55 \%$ & $4 \%$ \\
\hline 8. & Do you like e-learning? & & $80 \%$ & $15 \%$ & $5 \%$ \\
\hline
\end{tabular}

Table 2: Results of the survey for students: advantages according to students

\begin{tabular}{|l|l|l|l|l|}
\hline No. & BENEFITS ACCORDING TO STUDENTS & YES & NO & NO RESPONSE \\
\hline 1. & Up-to-date work & $91 \%$ & $7 \%$ & $2 \%$ \\
\hline 2. & Individualized work & $85 \%$ & $12 \%$ & $3 \%$ \\
\hline 3. & Availability and clarity of teaching materials & $92 \%$ & $7 \%$ & $1 \%$ \\
\hline 4. & Link to the useful on-line didactic and multimedia content & $86 \%$ & $11 \%$ & $3 \%$ \\
\hline 5. & Interesting e-course & $83 \%$ & $16 \%$ & $1 \%$ \\
\hline 6. & The usefulness of e-course for language learning exam preparation & $88 \%$ & $10 \%$ & $2 \%$ \\
\hline 7. & Communication with teachers and having the work supervised & $82 \%$ & $15 \%$ & $3 \%$ \\
\hline 8. & Preparation and delivery of assignments & $89 \%$ & $9 \%$ & $2 \%$ \\
\hline 9. & On-line assessment (preliminary exams, tests, etc.) & $56 \%$ & $42 \%$ & $2 \%$ \\
\hline
\end{tabular}

Table 3: Results of the survey for students: disadvantages according to students

\begin{tabular}{|l|l|l|l|l|}
\hline No. & DISADVANTAGES ACCORDING TO STUDENTS & YES & NO & NO RESPONSE \\
\hline 1. & Level of difficulty of e-learning in IT terms & $28 \%$ & $66 \%$ & $6 \%$ \\
\hline 2. & Lack of equipped classrooms & $45 \%$ & $50 \%$ & $5 \%$ \\
\hline
\end{tabular}




\begin{tabular}{|l|l|l|l|l|}
\hline 3. & Poorly organized teaching materials & $29 \%$ & $66 \%$ & $5 \%$ \\
\hline 4. & A lot of time spent on search for the useful materials & $32 \%$ & $62 \%$ & $6 \%$ \\
\hline 5. & Unnatural communication with teachers & $32 \%$ & $63 \%$ & $5 \%$ \\
\hline 6. & $\begin{array}{l}\text { Continuous insight into the work of students and supervision of their } \\
\text { progress }\end{array}$ & $50 \%$ & $45 \%$ & $5 \%$ \\
\hline 7. & Greater demands for students & $24 \%$ & $71 \%$ & $5 \%$ \\
\hline 8. & Preparation and delivery of assignments & $39 \%$ & $54 \%$ & $7 \%$ \\
\hline 9. & Complicated assessments & $23 \%$ & $72 \%$ & $5 \%$ \\
\hline
\end{tabular}

Table 4: Results of the survey for teachers $(\mathrm{N}=12)$

\begin{tabular}{|c|c|c|c|c|c|}
\hline No. & QUESTION & \multicolumn{2}{|l|}{ YES } & NO & $\begin{array}{l}\text { NO } \\
\text { RESPONSE }\end{array}$ \\
\hline 1. & $\begin{array}{l}\text { Do you use e-learning in the current academic } \\
\text { year? }\end{array}$ & \multicolumn{2}{|l|}{$67 \%$} & $33 \%$ & $0 \%$ \\
\hline 2. & If NO, have you ever used it? & \multicolumn{2}{|l|}{$25 \%$} & $8 \%$ & $67 \%$ \\
\hline 3. & $\begin{array}{l}\text { If NO, why not? } \\
\text { Choose an answer: } \\
\text { 1.Insufficient IT knowledge } \\
\text { 2. preferring standard language teaching } \\
\text { 3. lack of e-learning training for teachers } \\
\text { 4. poor interest of students }\end{array}$ & \multicolumn{2}{|l|}{$0 \%$} & $\begin{array}{l}33 \% \\
\\
\\
0 \% \\
8 \% \\
0 \% \\
22 \% \\
\end{array}$ & $67 \%$ \\
\hline 4. & Do you wish to use it in future? & \multicolumn{2}{|l|}{$42 \%$} & $0 \%$ & $58 \%$ \\
\hline 5. & If you use e-learning, which platform you use? & $\begin{array}{l}\text { Duel } \\
\text { Merlin } \\
\text { Duel i Merlin }\end{array}$ & $\begin{array}{l}14 \% \\
43 \% \\
36 \%\end{array}$ & $0 \%$ & $7 \%$ \\
\hline 6. & How long have you been using e-learning? & $\begin{array}{l}\text { Less than } 5 \text { years } \\
\text { More than } 5 \text { years }\end{array}$ & $\begin{array}{l}9 \% \\
83 \%\end{array}$ & $0 \%$ & $8 \%$ \\
\hline 7. & $\begin{array}{l}\text { How many e-courses do you actively use on } \\
\text { Duel? }\end{array}$ & $\begin{array}{l}1 \text { course } \\
2 \text { courses } \\
6 \text { courses } \\
\text { other responses } \\
\end{array}$ & $\begin{array}{l}17 \% \\
8 \% \\
8 \% \\
17 \% \\
\end{array}$ & $0 \%$ & $50 \%$ \\
\hline 8. & $\begin{array}{l}\text { How many e-courses do you actively use on } \\
\text { Merlin? }\end{array}$ & $\begin{array}{l}1 \text { courses } \\
2 \text { courses } \\
3 \text { courses per semester } \\
5 \text { courses } \\
6 \text { courses } \\
8 \text { courses }\end{array}$ & $\begin{array}{l}17 \% \\
17 \% \\
8 \% \\
\\
8 \% \\
17 \% \\
8 \% \\
\end{array}$ & $0 \%$ & $25 \%$ \\
\hline 9. & Which activities do you use? & $\begin{array}{l}\text { Assignment } \\
\text { dictionary } \\
\text { lesson } \\
\text { forum } \\
\text { test } \\
\text { dialogue } \\
\text { wiki } \\
\end{array}$ & $\begin{array}{l}27 \% \\
24 \% \\
22 \% \\
13 \% \\
5 \% \\
3 \% \\
3 \% \\
\end{array}$ & $0 \%$ & $3 \%$ \\
\hline 10. & Which activities you use most? & $\begin{array}{l}\text { Assignment } \\
\text { Lesson } \\
\text { forum } \\
\text { dictionary } \\
\text { other responses }\end{array}$ & \begin{tabular}{l|}
$22 \%$ \\
$22 \%$ \\
$17 \%$ \\
$5 \%$ \\
$11 \%$ \\
\end{tabular} & $0 \%$ & $22 \%$ \\
\hline 11. & Which resources do you use? & $\begin{array}{l}\text { File } \\
\text { Link } \\
\text { Webpage } \\
\text { book } \\
\text { label } \\
\text { map }\end{array}$ & $\begin{array}{l}33 \% \\
30 \% \\
17 \% \\
7 \% \\
7 \% \\
3 \%\end{array}$ & $0 \%$ & $3 \%$ \\
\hline 12. & Which resources you use most? & $\begin{array}{l}\text { File } \\
\text { Link }\end{array}$ & $\begin{array}{l}33 \% \\
28 \%\end{array}$ & $0 \%$ & $28 \%$ \\
\hline
\end{tabular}




\begin{tabular}{|l|l|l|l|l|}
\hline & & other responses & $11 \%$ & \\
\hline 13. & Do you like e-learning? & $92 \%$ & $0 \%$ & $8 \%$ \\
\hline 14. & Do you consider it demanding in the IT sense? & $25 \%$ & $67 \%$ & $8 \%$ \\
\hline 15. & Does it facilitate you work? & $92 \%$ & $0 \%$ & $8 \%$ \\
\hline 16. & Is it sufficiently used by students? & $0 \%$ & $92 \%$ & $8 \%$ \\
\hline 17. & Do you use it sufficiently? & $42 \%$ & $50 \%$ & $8 \%$ \\
\hline 18. & Does it improve the quality of work? & $92 \%$ & $0 \%$ & $8 \%$ \\
\hline 19. & $\begin{array}{l}\text { Do you have technical support in your institution } \\
\text { in the creation of e-course? }\end{array}$ & $42 \%$ & $50 \%$ & $8 \%$ \\
\hline
\end{tabular}

Table 5: Results of the survey for teachers: advantages of e-learning

\begin{tabular}{|l|l|l|l|l|}
\hline No. & ADVANTAGES ACCORDING TO TEACHERS & YES & NO & NO RESPONSE \\
\hline 1. & E-course availability & $100 \%$ & $0 \%$ & $0 \%$ \\
\hline 2. & Individualized learning & $100 \%$ & $0 \%$ & $0 \%$ \\
\hline 3. & Availability and clarity of teaching materials & $100 \%$ & $0 \%$ & $0 \%$ \\
\hline 4. & Link to the useful on-line didactic and multimedia content & $100 \%$ & $0 \%$ & $0 \%$ \\
\hline 5. & Presence of all four language competencies & $92 \%$ & $8 \%$ & $0 \%$ \\
\hline 6. & Interesting e-course & $100 \%$ & $0 \%$ & $0 \%$ \\
\hline 7. & Usefulness of e-course to learn the language and prepare exams & $100 \%$ & $0 \%$ & $0 \%$ \\
\hline 8. & Communication with students & $92 \%$ & $8 \%$ & $0 \%$ \\
\hline 9. & Supervising students' work & $100 \%$ & $0 \%$ & $0 \%$ \\
\hline 10. & Preparation and implementation of assessment & $33 \%$ & $67 \%$ & $0 \%$ \\
\hline
\end{tabular}

Table 6: Results of the survey for teachers: disadvantages of e-learning

\begin{tabular}{|l|l|l|l|l|}
\hline No. & DISADVANTAGES ACCORDING TO TEACHERS & YES & NO & NO RESPONSE \\
\hline 1. & Level of difficulty in terms of IT & $50 \%$ & $50 \%$ & $0 \%$ \\
\hline 2. & Technical drawbacks of e-learning platforms & $75 \%$ & $8 \%$ & $17 \%$ \\
\hline 3. & Duration of the e-course preparation & $75 \%$ & $25 \%$ & $0 \%$ \\
\hline 4. & Organization of teaching materials & $42 \%$ & $58 \%$ & $0 \%$ \\
\hline 5. & A lot of time spent on the search of useful on-line content & $58 \%$ & $42 \%$ & $0 \%$ \\
\hline 6. & Unnatural communication with students & $15 \%$ & $85 \%$ & $0 \%$ \\
\hline 7. & Insufficient use of e-courses by students & $92 \%$ & $8 \%$ & $0 \%$ \\
\hline 8. & Students do not recognize the usefulness of e-learning & $75 \%$ & $25 \%$ & $0 \%$ \\
\hline 9. & Passivity in the execution of individual tasks & $75 \%$ & $25 \%$ & $0 \%$ \\
\hline 10. & Complicated assessment & $83 \%$ & $17 \%$ & $0 \%$ \\
\hline
\end{tabular}

